\title{
Autoantibodies in Autoimmune Liver Disease-Clinical and Diagnostic Relevance
}

\author{
Marcial Sebode ${ }^{1 \dagger}$, Christina Weiler-Normann ${ }^{1,2+}$, Timur Liwinski ${ }^{1 \dagger}$ and \\ Christoph Schramm ${ }^{1,2 *}$ \\ ${ }^{1} 1$ st Department of Medicine, University Medical Centre Hamburg-Eppendorf, Hamburg, Germany, ${ }^{2}$ Martin Zeitz Centre for \\ Rare Diseases, University Medical Centre Hamburg-Eppendorf, Hamburg, Germany
}

OPEN ACCESS

Edited by:

Ralf J. Ludwig,

University of Lübeck, Germany

Reviewed by:

Urs Christen,

Goethe University Frankfurt,

Germany

Luis Eduardo Coelho

Andrade,

Federal University of

São Paulo, Brazi

${ }^{*}$ Correspondence: Christoph Schramm

cschramm@uke.de

tThese authors have contributed equally to this work.

Specialty section:

This article was submitted to Immunological Tolerance and

Regulation,

a section of the journal

Frontiers in Immunology

Received: 29 January 2018 Accepted: 12 March 2018

Published: 27 March 2018

Citation:

Sebode M, Weiler-Normann C, Liwinski T and Schramm C (2018)

Autoantibodies in Autoimmune Liver

Disease-Clinical and Diagnostic

Relevance.

Front. Immunol. 9:609.

doi: 10.3389/fimmu.2018.00609
Testing for liver-related autoantibodies should be included in the workup of patients with hepatitis or cholestasis of unknown origin. Although most of these autoantibodies are not disease specific, their determination is a prerequisite to diagnose autoimmune hepatitis $(\mathrm{AlH})$ and primary biliary cholangitis (PBC), and they are components of the diagnostic scoring system in these diseases. In primary sclerosing cholangitis (PSC), on the other hand, autoantibodies are frequently present but play a minor role in establishing the diagnosis. In PSC, however, data on antibodies suggest a link between disease pathogenesis and the intestinal microbiota. This review will focus on practical aspects of antibody testing in the three major autoimmune liver diseases $\mathrm{AlH}, \mathrm{PBC}$, and PSC.

Keywords: autoimmune hepatitis, primary biliary cholangitis, primary sclerosing cholangitis, antinuclear antibodies, smooth muscle antibodies, antimitochondrial antibodies, soluble liver antigen/liver-pancreas antigen, serology

\section{INTRODUCTION}

Testing for liver-related autoantibodies should be included in the workup of patients with hepatitis or cholestasis of unknown origin. Although most of these autoantibodies are not disease specific, their determination is a prerequisite to diagnose autoimmune hepatitis (AIH) and primary biliary cholangitis (PBC), and they are components of the diagnostic scoring system in these diseases $(1,2)$ (Table 1). In primary sclerosing cholangitis (PSC), on the other hand, autoantibodies are frequently present but play a minor role in establishing the diagnosis, which is based on cholangiography. In PSC, however, data on antibodies suggest a link between disease pathogenesis and the intestinal microbiota (3).

Abbreviations: AIH, autoimmune hepatitis; AMA, antimitochondrial antibodies; ANA, antinuclear antibodies; ASGPR, asialoglycoprotein receptor; BEC, biliary epithelial cells; CD, cluster of differentiation; CYP, cytochrome P450; DILI, drug-induced liver injury; DNA, deoxyribonucleic acid; ds, double stranded; EASL, European Association for the Study of the Liver; ELISA, enzyme-linked immunosorbent assay; ERCP, endoscopic retrograde cholangiopancreatography; FTCD, formiminotransferase cyclodeaminase; FTSZ, filamenting temperature-sensitive mutant Z; GP, glycoprotein; HCC, hepatocellular carcinoma; HCV, viral hepatitis C; HLA, human leukocyte antigen; IAC, IgG4-associated cholangitis; IBD, inflammatory bowel disease; IFT, indirect immunofluorescence testing; IG, immunoglobulin; LC1, liver cytosol type 1; LKM, liver-kidney microsome; MRCP, magnetic-resonance cholangiography; p-ANCA, antineutrophil cytoplasmatic antibodies with a perinuclear staining pattern; PBC, primary biliary cholangitis; PDC-E2, pyruvate-dehydrogenase E2; PSC, primary sclerosing cholangitis; SEPSECS, $O$-phosphoseryl-tRNA:selenocysteine-tRNA synthase; SLA/LP, soluble liver antigen/liver-pancreas antigen; SLE, systemic lupus erythematodes; SMA, smooth muscle antibodies; SS, single stranded; TBB-5, beta-tubulin isoform 5; UGT, uridine glycuronosyl transferase; VGT, vascular/glomerular/tubular. 
TABLE 1 | Autoantibodies in autoimmune liver diseases.

\begin{tabular}{|c|c|c|c|c|c|c|}
\hline Antibody & Screening test & Confirmatory test & $\begin{array}{l}\text { Positive in the following } \\
\text { liver diseases }\end{array}$ & $\begin{array}{l}\text { Recommended as initial } \\
\text { screening for AILD }\end{array}$ & $\begin{array}{l}\text { Prognostic } \\
\text { value for AILD }\end{array}$ & Target antigen \\
\hline ANA & SKL IFT & $\begin{array}{l}\text { HEp-2 IFT (identification } \\
\text { of a specific pattern) } \\
\text { ELISA, WB (for selected } \\
\text { nuclear antigens) }\end{array}$ & $\begin{array}{c}\text { AlH1 } \\
\text { PBC } \\
\text { PSC } \\
\text { HBV } \\
\text { HCV } \\
\text { DILI } \\
\text { NAFLD }\end{array}$ & Yes & $\begin{array}{l}\text { In PBC yes } \\
\text { (only gp210) }\end{array}$ & $\begin{array}{l}\text { In AlH: chromatin, histones, } \\
\text { centromere, ds- and ss-DNA, } \\
\text { cyclin A, ribonucleoproteins } \\
\text { and other nuclear antigens } \\
\text { In PBC: centromere, lamin-B- } \\
\text { receptor, sp100, gp210 }\end{array}$ \\
\hline $\begin{array}{l}\text { Anti-SMA } \\
\text { anti-F-actin }\end{array}$ & SKL IFT & $\begin{array}{l}\text { ELISA, WB } \\
\text { IFT on fibroblasts } \\
\text { (VSM47) }\end{array}$ & AlH1 & Yes & Unclear & $\begin{array}{l}\text { (Filamentous) actin, tubulin, or } \\
\text { intermediate filaments }\end{array}$ \\
\hline Anti-LKM-1 & SKL IFT & ELISA, WB & $\begin{array}{l}\mathrm{AlH} 2 \\
\mathrm{HCV}\end{array}$ & Yes & In AlH yes & CYP 2D6 \\
\hline Anti-SLA/LP & ELISA, WB & & AlH1 & Yes & Unclear & SepSecS \\
\hline Anti-LC1 & SKL IFT & $\begin{array}{l}\text { WB } \\
\text { Double immunodiffusion } \\
\text { assay }\end{array}$ & $\begin{array}{l}\mathrm{AlH} 2 \\
\mathrm{HCV}\end{array}$ & No & Unclear & FTCD \\
\hline Anti-LKM-2 & WB & & Tielinic acid-induced DILI & No & & CYP 2 C9 \\
\hline Anti-LKM-3 & WB & ELISA & $\begin{array}{l}\mathrm{AlH} 2 \\
\mathrm{HCV} \\
\mathrm{HDV}\end{array}$ & No & & UGTs \\
\hline p-ANCA/p-ANNA & $\begin{array}{l}\text { IFT on } \\
\text { formaldehyde- } \\
\text { fixed neutrophils }\end{array}$ & ELISA & $\begin{array}{l}\text { AlH } \\
\text { PSC } \\
\text { HBV } \\
\mathrm{HCV}\end{array}$ & No & Unclear & Unclear, tubulin-beta chain? \\
\hline Anti-ASGPR & ELISA, WB & & $\begin{array}{l}\text { AlH } \\
\text { PBC } \\
\text { HBV } \\
\text { HCV }\end{array}$ & No & Unclear & ASGPR \\
\hline AMA & SKL IFT & $\begin{array}{l}\text { HEp-2 IFT } \\
\text { ELISA, WB }\end{array}$ & $\begin{array}{c}\text { PBC } \\
\text { Variant syndromes } \\
\text { Acute liver failure }\end{array}$ & Yes & No & $\begin{array}{l}\text { Lipoylated domains of E3 } \\
\text { binding protein, various } \\
\text { epitopes of pyruvate- } \\
\text { dehydrogenase complex, } \\
\text { 2-oxo-acid dehydrogenase } \\
\text { complex, branched chain } \\
\text { 2-oxo-acid dehydrogenase } \\
\text { complex }\end{array}$ \\
\hline $\begin{array}{l}\text { Anti-Kelch-like } \\
\text { 12-antibodies, } \\
\text { anti-hexokinase1- } \\
\text { antibodies }\end{array}$ & ELISA, WB & & PBC & Unclear & Unclear & Kelch like 12, hexokinase E1 \\
\hline Anti-GP2 IgA & $\mathrm{IFT}$ & & PSC & No & In PSC yes & Glycoprotein 2 \\
\hline
\end{tabular}

AlH, autoimmune hepatitis; AlH1 or 2, autoimmune hepatitis type 1 or 2; AlLD, autoimmune liver diseases; AMA, antimitochondrial antibodies; ANA, antinuclear antibodies; ASGPR, asialoglycoprotein receptor; CYP, cytochrome P450; DILI, drug-induced liver injury; DNA, deoxyribonucleic acid; ds, double stranded; ELISA, enzyme-linked immunosorbent assay; FTCD, formiminotransferase cyclodeaminase; GP, glycoprotein; HBV, viral hepatitis B; HCV, viral hepatitis C; HDV, viral hepatitis D; HEp-2 IFT, indirect immunofluorescence testing on HEp-2 cells; IFT, indirect immunofluorescence testing; LC1, liver cytosol type 1; LKM, liver-kidney microsome; NAFLD, non-alcoholic fatty liver disease; SKL IFT, indirect immunofluorescence testing on rodent stomach, kidney, and liver tissue; $p$-ANCA, antineutrophil cytoplasmatic antibodies with a perinuclear staining pattern; PBC, primary biliary cholangitis; PSC, primary sclerosing cholangitis; SEPSECS, O-phosphoseryl-tRNA:selenocysteine-tRNA synthase; SLAVLP, soluble liver antigen/liver-pancreas antigen; SMA, smooth muscle antibodies; ss, single stranded; UGT, uridine glycuronosyl transferase; WB, western blot/immunoblot.

In Europe, screening for liver-related autoantibodies is traditionally conducted using indirect immunofluorescence testing (IFT) on rodent tissue slices (Table 2). Cutoff levels for titers included in diagnostic scores for AIH and PBC use IFT as a standard. In other parts of the world, solid-phase test systems are widely used and to date it is unclear, whether this results in altered sensitivity or specificity of the tests applied and how these findings can be translated into diagnostic scores. IFT has the advantage of not only assessing the titer of the autoantibodies but also the fluorescence pattern, which may provide additional information on the presence, e.g., of PBC-defining antinuclear antibodies (ANA). Therefore, fluorescence pattern of ANA should always be reported together with the antibody titer. It is important to note, however, that IFT is a subjective method that requires an experienced lab technician and that international standards for testing are currently lacking. Also, titers may differ between labs 
TABLE 2 | Recommended serologic first line diagnostics for autoimmune liver diseases.

\begin{tabular}{ll}
\hline Test assay & Antibodies detected \\
\hline SKL IFT & ANA \\
& Anti-SMA \\
& Anti-LKM \\
& AMA \\
HEp-2 IFT & ANA patterns indicative of antibodies to mitochondria (AMA), \\
& gp210, sp100, and centromere \\
ELISA or WB & Anti-SLALP
\end{tabular}

AMA, antimitochondrial antibodies; ANA, antinuclear antibodies; ELISA, enzyme-linked immunosorbent assay; GP, glycoprotein; HEP-2 IFT, indirect immunofluorescence testing on HEp-2 cells; LKM, liver-kidney microsome; SMA, smooth muscle antibodies; SKL IFT, indirect immunofluorescence testing on rodent stomach, kidney, and liver tissue; SLA/LP, soluble liver antigen/liver-pancreas antigen; WB, western blot/ immunoblot.

due to different substrates used, and, therefore, the lab-specific reference values should be noted.

The following review will focus on practical aspects of antibody testing in the three major autoimmune liver diseases $\mathrm{AIH}$, $\mathrm{PBC}$, and PSC.

\section{AUTOANTIBODIES IN AIH}

\section{Introduction \\ Diagnosis of AlH}

Autoimmune hepatitis is a chronic inflammatory liver disease with unknown etiology $(1,4,5)$. The diagnosis of AIH is based on a combination of typical findings, which are not disease specific and on the exclusion of other liver diseases, such as viral hepatitis (6-8). It is assumed that $\mathrm{AIH}$ is a $\mathrm{T}$ cell-mediated disease. However, there are hints at a relevant role for a humoral immune response in $\mathrm{AIH}$ pathogenesis: autoantibodies can frequently be detected, plasma cells are enriched in hepatic infiltrates and immunoglobulin $\mathrm{G}$ ( $\mathrm{IgG}$ )/gammaglobulins serve as a diagnostic and disease activity markers. Nevertheless, the exact pathogenetic relevance of this humoral immune response for $\mathrm{AIH}$ is unclear and has not been investigated in detail (Table 1). The antigens that are targeted by autoantibodies in AIH have been identified in most cases. Still, it is uncertain whether these autoantigens play a relevant role for the induction or preservation of chronic liver inflammation in $\mathrm{AIH}$.

The presence of AIH-related autoantibodies supports the diagnosis of AIH. However, most autoantibodies being associated with $\mathrm{AIH}$ have a relatively low disease specificity (Table 1). In the setting of acute or even chronic hepatitis of an etiology other than AIH, and even in healthy persons, liver autoantibodies can frequently be found. Besides, the presence of autoantibodies is not a prerequisite for the diagnosis of AIH: around $10-15 \%$ of patients present without known autoantibodies ("seronegative" $\mathrm{AIH}$ ) or develop them during the course of disease after an acute onset.

\section{Methods of Testing}

As mentioned earlier, IFT on rodent kidney, liver, and stomach tissue and on HEp-2 cells is recommended as the standard method for the detection of liver autoantibodies (9). It is important to note that IFT testing is a subjective method and titers may vary depending on the laboratory performing the test. Antibody titers above 1:40 have a higher specificity for $\mathrm{AIH}$, but it is unknown whether very high titers (e.g., >1:640) are associated with an even higher specificity. IFT enables the simultaneous analysis of most of the antibodies that are relevant for autoimmune liver diseases. HEp-2 cells with their prominent nuclei help to identify specific patterns of ANA. HEp-2 cells should not be used for initial screening for the presence of ANA since low titer antibodies can frequently be found in healthy subjects using these cells (10). Therefore, screening for ANA should be performed on rodent kidney, liver, and stomach tissue. In the case of positivity, the pattern of ANA should then be analysed on HEp-2 cells (9). The fluorescence pattern of ANA on HEp- 2 cells provides additional diagnostic information: a pattern of multiple "nuclear dots" or a "nuclear rim" pattern suggest the presence of anti-sp100 or anti-gp210, respectively, and thereby hint at the diagnosis of $\mathrm{PBC}$ or a variant syndrome of $\mathrm{AIH}$ with features of PBC (see below section on autoantibodies in $\mathrm{PBC}$ ). In Europe, there is consensus that solid-phase assays such as enzyme-linked immunosorbent assays (ELISA) or immunoblots should only be used to confirm the results of IFT, but not for initial screening of ANA. However, in the USA, ELISA are frequently used for screening purposes (4). For the diagnostic workup of autoimmune liver diseases, anti-soluble liver antigen/ liver-pancreas antibodies (anti-SLA/LP) should already initially be tested for by ELISA or immunoblot since these autoantibodies cannot be detected by IFT and have high specificity for AIH.

\section{Subclassification of AlH According to Autoantibody Pattern}

Next to their diagnostic value, certain autoantibodies have been associated with a different clinical presentation and prognosis of AIH. These associations have led to the classification of type 1 and type $2 \mathrm{AIH}$. Type $1 \mathrm{AIH}$ is the predominant type of $\mathrm{AIH}$ in adults and children and is defined by the presence of ANA and/or antismooth muscle antibodies (anti-SMA) (7). Anti-SMA (and especially anti-actin antibodies) have been associated with inflammatory activity of AIH in adult patients (11). However, these results still need to be validated. Type 2 AIH (about 5-10\% of all AIH patients) is typically defined by anti-liver-kidney microsomal type 1 antibodies (anti-LKM-1) or, in rare cases, by anti-LKM-3 and/or anti-liver cytosol type 1 antibodies (antiLC1) (12-14). Type 2 AIH presents at a younger age, often in childhood, and is associated with a more aggressive disease course than type $1 \mathrm{AIH}(12,15)$. It is still controversial whether the presence of anti-SLA/LP defines a third subgroup of AIH (type $3 \mathrm{AIH}$ ) with a potentially more aggressive clinical course or whether anti-SLA/LP-positive AIH patients experience a clinical course similar to type $1 \mathrm{AIH}$ patients (16-19). In 5-10\% of AIH patients, anti-SLA/LP are present in combination with ANA and/ or anti-SMA. In up to $10 \%$ of AIH patients, anti-SLA/LP are the sole antibodies detected (20), a fact that mandates their testing for the diagnosis of AIH.

\section{Special Considerations in Children}

Antibody testing in pediatric patients demands special attention. Titers for most liver autoantibodies seem to correlate with age: in 
children, lower titers (1:20 for ANA and anti-SMA and 1:10 for anti-LKM-1) can be diagnostic for AIH, whereas in adults, higher titers of ANA (1:80-1:160) can also be found in healthy individuals $(9,21)$. Therefore, the physician should be informed by the laboratory on any antibody titer that is detected and interpret the results according to patient's age.

\section{Repeated Testing of Autoantibodies}

Particularly in pediatric patients with autoimmune liver diseases, titers of liver-related autoantibodies can correlate with disease activity and response to treatment may be paralleled by reduction or even disappearance of antibody titers $(21,22)$. Thus, retesting of autoantibodies can be reasonable in children, as it can add information on the depth of remission achieved.

Retesting of autoantibodies for adult patients with AIH cannot be recommended in general, but can be helpful in special clinical settings. In cases of acute hepatitis and initially negative autoimmune serology, antibody testing should be repeated after 3-6 months since antibodies can appear during the course of disease. In adult patients, a variant syndrome of AIH with features of additional PBC can develop even several years after the diagnosis of classical AIH. Therefore, IFT should be repeated to screen for PBC-specific ANA or antimitochondrial antibodies (AMA) whenever cholestatic liver enzymes remain or become elevated or when symptoms suggestive of PBC develop in an AIH patient. Currently, regular retesting of autoantibodies in adult patients as a surrogate marker for inflammatory activity is not recommended.

\section{Antinuclear Antibodies}

Antinuclear antibodies were the first autoantibodies to be associated with AIH (23). However, they lack disease specificity. About $50-75 \%$ of AIH patients are ANA-positive (with or without anti-SMA) (24). ANA can also be detected in healthy persons or patients with other liver diseases such as fatty liver disease, druginduced liver injury (DILI) disease, or viral hepatitis. The pattern of ANA in AIH often is speckled or homogenous. It is uncertain whether a distinct pattern of ANA has a higher specificity for AIH. ANA in AIH are directed against several antigens such as chromatin, histones, centromere, double-(ds) and single-(ss) stranded deoxyribonucleic acid (DNA), cyclin A, ribonucleoproteins or other nuclear antigens that have not yet been identified (25-29). A biochemical differentiation of these antigens is not recommended because they have not been associated with a certain clinical course or a higher diagnostic specificity for AIH. It is important to acknowledge that up to $20 \%$ of $\mathrm{AIH}$ patients may display anti-dsDNA antibodies. This may cause confusion with the diagnosis of systemic lupus erythematodes, which has to be ruled out in patients with respective clinical findings. In rare cases, both diseases may occur together (30).

\section{Antismooth Muscle Antibodies}

Similar to ANA, anti-SMA have been associated with AIH since the early days of the clinical definition of AIH. They are also not disease specific and can be detected in various liver diseases such as fatty liver disease $(31,32)$. Anti-SMA are present in about $50 \%$ of patients with type I AIH and can be the only detectable autoantibody. In IFT, anti-SMA react with the smooth muscles of the lamina propria and muscularis mucosae of the stomach or arterial walls of the liver. On kidney tissue, anti-SMA show different staining patterns: the vascular/glomerular and the vascular/ glomerular/tubular (VGT) patterns are more specific for $\mathrm{AIH}$ than the vascular $(\mathrm{V})$ pattern $(9,24)$. The VGT pattern can be confirmed by IFT performed on fibroblasts or vascular smooth muscle cells (VSM47) (33). On a molecular level, anti-SMA are a heterogeneous group of antibodies showing reactivity against actin, tubulin or intermediate filaments (34). Sera showing the VGT pattern react in $80 \%$ with filamentous actin (F-actin) (9, $33,35)$. Actin is a ubiquitous contractile protein. The presence of anti-F-actin antibodies can be confirmed by solid-phase assays, such as ELISA (36). Anti-SMA showing reactivity against F-actin seem to be more specific for AIH, but can also be detected in other liver diseases $(35,37)$.

\section{Anti-Liver-Kidney Microsomal Antibodies (Anti-LKM)}

Anti-LKM-1, but also anti-LKM-3 are defining type 2 AIH (9). In IFT, anti-LKM stain, the cytoplasm of hepatocytes and the proximal, larger renal tubuli, but not parietal cells of the stomach (38). By contrast, AMA in PBC stain the mitochondria-rich, distal, smaller renal tubuli, and gastric parietal cells. ELISA tests are recommended to confirm positivity for anti-LKM in IFT (39). The autoantigen that is recognized by anti-LKM-1 in AIH is cytochrome P450 (CYP) 2D6 (40-44). Anti-LKM-1 are not AIH-specific and can also be found in patients with chronic viral hepatitis $\mathrm{C}(\mathrm{HCV})(45,46)$. However, the epitopes that are targeted by anti-LKM-1 in HCV-infected patients differ from those in patients with AIH $(47,48)$. Anti-LKM-2 have been detected in cases of tielinic acid-induced DILI, a drug that has been withdrawn from the market (49). In contrast to anti-LKM-1, anti-LKM-2 target a different isoform of the cytochrome P 450, namely CYP 2C9. Anti-LKM-3 can be found in few patients with $\mathrm{AIH}$, but also in $\mathrm{HCV}$ and viral hepatitis $\mathrm{D}$. They recognize members of the uridine glycuronosyl transferases family 1 (26, $27,50,51)$.

\section{Anti-Soluble Liver Antigen/Liver-Pancreas Antigen Antibodies (Anti-SLA/LP)}

Anti-SLA/LP have the highest specificity for AIH among all AIH-related autoantibodies (9). However, they are present in only about $10-20 \%$ of patients. Due to their high specificity, anti-SLA/ LP should be tested routinely when AIH is suspected or in any case of unclear elevation of liver enzymes. Anti-SLA/LP cannot be detected by IFT and need to be tested for by ELISA or Western blot (52). The cytosolic autoantigen targeted by anti-SLA/LP was described independently by different groups and has been characterized later on as $O$-phosphoseryl-tRNA:selenocysteine-tRNA synthase (SepSecS), a synthase (S) converting O-phosphoseryltRNA (Sep) to selenocysteinyl-tRNA (Sec) (20, 53-58). AntiSLA/LP belong to the IgG1 subtype of immunoglobulins and recognize an immunodominant epitope at the carboxy terminus of the SepSecS protein (59). Interestingly, the epitopes of SepSecS recognized by anti-SLA/LP-antibodies overlap with CD4+ T cell epitopes. This points to a relevant pathogenetic role of SepSecS 
for the subgroup of anti-SLA/LP-positive AIH patients (60). Anti-SLA/LP have been associated with the presence of a subtype of ANA (anti-Ro52) (61). Unexplained adverse pregnancy outcomes in AIH were highly associated with the presence anti-SLA/LP and anti-Ro52, potentially due to antibody-induced congenital heart block (62).

\section{Other Antibodies Associated With AlH} Anti-Liver Cytosol Type 1 Antibodies (Anti-LC1)

Anti-LC1 antibodies directed against liver cytosol 1 (anti-LC1) target epitopes of the enzyme formiminotransferase cyclodeaminase (63). They are present in about $30 \%$ of type $2 \mathrm{AIH}$ patients, alone or in combination with anti-LKM-1 $(64,65)$. In IFT, anti-LC1 stain hepatocytes but spare the centrilobular areas of the liver. By contrast, anti-LKM-1 stain hepatocytes throughout the liver lobule. When both antibodies are coexistent, antiLKM-1 cover the spared areas of anti-LC1. Thereby, anti-LKM-1 can mask the presence of anti-LC1. Solid-phase assays help to identify anti-LC-1 (65). When anti-LC1 are the sole antibodies being detected, they strongly support the diagnosis of type $2 \mathrm{AIH}$. However, anti-LC1 are not AIH specific and can also be detected in patients with $\mathrm{HCV}$ (64).

\section{Antineutrophil Cytoplasmatic Antibodies With a Perinuclear Staining Pattern (p-ANCA)}

The presence of $\mathrm{p}$-ANCA can support the diagnosis of AIH, especially in the absence of other autoantibodies (9). However, p-ANCA can also be detected in chronic viral hepatitis, inflammatory bowel disease (IBD), PSC or microscopic polyangiitis, and eosinophilic granulomatosis with polyangiitis (66-69). p-ANCA mainly react with myeloperoxidase. Atypical p-ANCA ( $\mathrm{p}$-ANNA), which are characterized by the retention of a perinuclear staining on formaldehyde-fixed neutrophils seem to be more specific for autoimmune liver diseases and IBD (9).

\section{Anti-Asialoglycoprotein Receptor Antibodies (Anti-ASGPR)}

Anti-ASGPR can be detected in $24-82 \%$ of AIH patients, depending on the diagnostic assay used (70). Anti-ASGPR target a liver-specific membrane receptor and seem to correlate with histological activity (70). However, anti-ASGPR are not disease specific and are also present in patients with chronic viral hepatitis or PBC.

\section{AMA in Patients With AlH}

Since IFT on the abovementioned rodent tissues allows the simultaneous detection of autoantibodies for different autoimmune liver diseases, $\mathrm{PBC}$-specific AMA are occasionally detected during the diagnostic workup for AIH. In this case, a variant syndrome of AIH with features of PBC should be suspected, often indicated by persistent elevation of cholestatic liver enzymes after the AIH component has reached remission. In some rare cases, AMA develop during the course of classical AIH with a novel elevation of cholestatic liver enzymes (2). In other rare instances, AMA can be detected in AIH patients without any other laboratory or histological signs of concomitant PBC. It is unclear whether this is an epiphenomenon, whether these cases represent a subform of
AIH or a very early stage of an AIH variant syndrome with additional PBC $(71,72)$. Additional treatment with UDCA should be decided upon on an individual basis. In acute AIH, AMA may be present as an unspecific sign of acute liver damage, and they usually disappear over time (73).

\section{Pathogenetic Role of Autoantibodies in AlH}

It is unclear whether autoantibodies substantially contribute to the pathogenesis of AIH (Table 1). Most knowledge on a potential pathogenetic role of autoantibodies in AIH derives from analyzes of anti-LKM. The cross-reaction of anti-LKM with homologous regions of CYP 2D6 and HCV hints at a viral infection being a possible trigger for type $2 \mathrm{AIH}$. Molecular mimicry has been proposed for several autoimmune diseases. However, it has not been convincingly shown that an acute viral infection is truly the disease initiating event for a substantial number of AIH patients. For type 2 AIH patients, an abnormal expression of CYP 2D6 as the respective autoantigen of antiLKM has been detected on the surface of hepatocytes (74). It is unclear, how autoantibodies in other types of AIH are able to target intracellular antigens. The release of nuclear or cytosolic antigens due to hepatocyte damage has been proposed as one possible mechanism. Another area of uncertainty is the fact that almost all of the antigens addressed by antibodies in $\mathrm{AIH}$ are not exclusively expressed in the liver, such as CYP 2D6, which is also expressed, e.g., in the central nervous system. Also, the target antigen of anti-SLA/LP is expressed in liver, pancreas, lungs, kidneys, and activated lymphocytes, but anti-SLA/LP have only been associated with $\mathrm{AIH}(55,57)$. Asialoglycoprotein receptor (ASGPR) is a hepatic C-type lectin expressed on the sinusoidal surface of hepatocytes physiologically and on the canalicular membrane of hepatocyctes under inflammatory conditions (70). A T cell-mediated immune reaction, overlapping in its targeted epitopes with the humoral immune response, has been identified for ASGPR, for CYP 2D6 $(75,76)$ and for SepSecS, the molecular target of anti-SLA/LP $(60,77)$.

\section{AUTOANTIBODIES IN PBC}

\section{Introduction Diagnosis of PBC}

Primary biliary cholangitis is a chronic non-suppurative granulomatous inflammation of the small intrahepatic bile ducts (2). The first description of this disease dates back more than 100 years (78) and historically, PBC was often diagnosed only postmortem (79). Around $90 \%$ of all affected patients are female, and the vast majority (>90\%) display autoantibodies. Clinically, PBC leads to elevation of cholestatic parameters and often a selective IgM elevation. In addition, many patients will have elevated cholesterol levels. Autoantibodies play a major role for the diagnosis of PBC: European Association for the Study of the Liver (EASL) recommends that in adult patients with chronic cholestasis and no likelihood of systemic disease, a diagnosis of $\mathrm{PBC}$ can be made based on elevated ALP and the presence of AMA at a titer of more 
than 1:40. In the absence of AMA, PBC-specific ANA can serve to diagnose the disease (2) (Table 1).

\section{Autoantibodies in PBC}

Autoantibodies, and especially AMA, are a hallmark of the disease: The first tests for detection of AMA were developed in the 1960s (80) and facilitated diagnosis and timely treatment later on. The development not only of refined testing for AMA but also the addition of other PBC-defining autoantibodies to the repertoire has led to an increasing proportion of $\mathrm{PBC}$ patients displaying autoantibodies and likely also to earlier diagnosis. Today, even non-invasive testing for AMA seems feasible as a recently published approach to test AMA in saliva has demonstrated (81). It remains unclear whether these autoantibodies are pathogenetically relevant. There has been some debate about AMA being responsible for fatigue in $\mathrm{PBC}$ and trials to evaluate the effect of an anti-CD20 treatment are on the way (82). In patients with suspected $\mathrm{PBC}$ and negative AMA-testing, $\mathrm{PBC}$-defining ANA should be sought (Table $\mathbf{1}$ ).

In all patients with unexplained chronic cholestasis or suspected PBC, autoantibody testing should be performed using IFT on rodent tissue and confirmation of fluorescence pattern using Hep-2 cells (see above) (2) Approximately 10\% of PBC patients will not display AMA $(2,83)$. In these patients, diagnostic accuracy is improved by testing for PBC-specific nuclear autoantibodies, which will be present in approximately half of the AMA-negative patients (84). In addition, some of the nuclear antibodies have been associated with prognosis (see below); therefore, antibody pattern may in clinical practice help to risk stratify patients.

\section{Antimitochondrial Antibodies}

Antimitochondrial antibodies have initially been described in patients with PBC by Dame Sheila Sherlock (80). These antibodies are directed against the pyruvate-dehydrogenase E2 (PDCE2) (85) subunit located in the inner mitochondrial membrane. In IFT, AMA lead to a typical cytoplasmic staining in rat liver and kidney slices, but they are often also visible on HEp-2 cells. The vast majority of PBC patients (exceeding 90\%) (86) display these antibodies (87), and they may occasionally be found years preceding an elevation of liver enzymes (see below). Increasingly often, AMA are detected, e.g., due to rheumatological screens in patients with normal liver enzymes $(88,89)$, usually at lower titers than in patients with overt PBC (90). A considerable proportion of patients with positive AMA but no signs of $\mathrm{PBC}$ will likely develop symptomatic $\mathrm{PBC}$ at some time point and therefore these patients should be followed clinically and biochemically $(91,92)$. Current data and guidelines do not support treatment in AMApositive persons without any elevated liver enzymes or signs of PBC $(2,83)$. Several subtypes of AMA have been identified (traditionally named M1-M9). In this historical classification, antibodies directed against M2, M4, M8, and M9 are associated with PBC. Nowadays, combined peptides covering these antigenic regions have been constructed (93) and are widely used in confirmatory solid-phase tests.

Antimitochondrial antibodies can be comprised of IgG, IgA (94), and IgM antibodies (95) or a combination thereof, whereby AMA of the IgG3 subtype and IgA directed against PDC-E2 have been associated with more severe disease (96). In a subgroup of patients, AMA seem to be solely comprised of IgM antibodies (REF). To date, it is unclear, whether testing systems should include the possibility to detect IgM antibodies.

AMA on IFT may be confused with other cytoplasmatic antibodies (e.g., cardiolipin antibodies), therefore, it is advisable to perform a confirmatory test using one of the ELISA or Western blot test systems, which include several of the known PDC epitopes.

Primary biliary cholangitis-specific autoantibodies should be sought in patients with chronic ( $>6$ months) elevation of cholestatic liver enzymes. Of note, patients with acute liver damage of any kind or liver failure may also display AMA (73). These usually disappear with the resolution of the acute disease.

\section{Anti-sp100 Antibodies}

In patients without AMA and persisting suspicion of $\mathrm{PBC}$, ANA should be sought by using IFT in HEp-2 cells. These antibodies will be present in around $30-50 \%$ of AMA-negative PBC patients and interestingly, have been described to be inversely correlated to the development of fibrosis (97). These ANA have so far have not been associated with any specific disease features. They are moderately specific for $\mathrm{PBC}$ and can rarely be detected in rheumatological diseases and in acute hepatitis of any origin $(33,98$, 99). Anti-sp100 result in a typical pattern of "nuclear dots" in IFT on HEp-2-cells (100); a confirmatory test (ELISA and Western Blot) is available (101).

\section{Anti-gp210 Antibodies and Anti-Lamin-B- Receptor Antibodies}

A subgroup of patients with PBC may display anti-gp210 or, rarely, anti-lamin-B-receptor antibodies in addition to AMA or even exclusively. Anti-gp210 (102) and anti-lamin-B-receptor (103) result in a "nuclear rim" pattern on IFT using HEp-2 cells, where anti-lamin-B-receptor antibodies usually result in a smooth staining and the anti-gp210-antibody appears as discontinuous staining on IFT. For anti-gp210, a confirmatory test is widely available; confirmatory testing for anti-lamin-Breceptor is subject to specialized laboratories. These antibodies are present in around $20 \%$ PBC patients, and in around $30-50 \%$ of AMA-negative patients and are considered specific for PBC. In addition, an unfavorable course of $\mathrm{PBC}$ has been associated with the presence of anti-gp210 in several studies (99, 104, 105), and a higher incidence of hepatocellular carcinoma has been reported in this patient cohort (106). Therefore, patients with these antibodies may warrant special attention in disease surveillance (83).

\section{Anti-Centromere Antibodies}

Anti-centromere have been described in patients with systemic sclerosis but may occasionally occur in PBC patients without features of systemic sclerosis. Clinically, anti-centromere have been associated with increased portal hypertension in these patients (99) and a poor prognosis $(107,108)$. Anti-centromere have recently also been associated with the development of kidney disease in PBC patients (109). 


\section{Anti-Kelch-Like 12 Antibodies, Anti-Hexokinase1 Antibodies}

Recently, two new autoantibodies, anti-Kelch-like 12 and antihexokinase1 have been described in PBC (110). So far, no clear associations with disease activity or clinical course have been established, and their prevalence in larger populations has yet to be established.

\section{Antibodies Found in Patients With PBC and Additional Signs of AlH}

Features of AIH may be present in $10-20 \%$ of patients who present with PBC. There are no generally accepted criteria to define these variant syndromes. In most patients, both diseases manifest simultaneously and in these patients, the Paris criteria have been established and endorsed by EASL to indicate additional AIH in a PBC patient $(2,111)$. AIH can be diagnosed if two of three criteria are present: (1) elevation of ALT levels $>5$ times upper limit the normal (ULN), (2) elevation of serum IgG levels $>2$ times ULN or positive anti-SMA, and (3) moderate to severe interface hepatitis on histology. In addition, the presence of anti-SLA/LP and anti-dsDNA may raise the suspicion of AIH in patients with PBC (112-114).

\section{AUTOANTIBODIES IN PSC}

\section{Introduction}

\section{Diagnosis of PSC}

Primary sclerosing cholangitis is a cholestatic liver disease of unknown origin that is characterized by progressive multifocal strictures of the extra- and/or intrahepatic bile ducts $(115,116)$. PSC is strongly associated with a unique phenotype of IBD, mostly presenting as a mild pancolitis (117). While the onset of PSC is often insidious, the natural course leads to liver cirrhosis, hepatobiliary malignancies, colon cancer, and episodes of superimposed bacterial cholangitis (118). This results in death or liver transplantation after a median time of approximately $15-20$ years $(119,120)$. PSC is usually characterized by a cholestatic profile of liver enzymes with a leading elevation of alkaline phosphatase. The diagnosis is nowadays established by magnetic-resonance cholangiography, since invasive direct cholangiography using endoscopic retrograde cholangiopancreatography is associated with markedly more complications, although it may yield a slightly higher sensitivity with regard to small bile ducts and the extrahepatic duct (121). Liver biopsy is usually not required to establish the diagnosis (122), unless concurrent AIH or smallduct PSC is suspected (123).

\section{Autoantibodies in PSC}

Although various serum antibodies have been described in patients with PSC, immune serology in PSC is generally considered unspecific and therefore of limited value to establish the diagnosis $(124,125)$ (Table 1). The most prevalent serum antibodies in PSC are p-ANCA, which can be found in up to $93 \%$ of patients, followed by ANA (8-77\%) and anti-SMA (0-83\%) (126). However, p-ANCA are also frequently found in patients with ulcerative colitis without PSC, in patients with AIH and to a lesser extent in $\mathrm{PBC}(127,128)$. Due to the lack of specificity, p-ANCA can support the diagnosis of PSC only in selected patients, mainly those lacking associated IBD.

\section{Antineutrophil Cytoplasmic Antibodies With Perinuclear Staining Pattern (p-ANCA)}

Usually, p-ANCA are demonstrated on IFT on alcohol-fixed human granulocytes. However, an experienced technician is required as evaluation of the staining patterns is challenging (129). The "atypical" pattern frequently found in sera of patients with PSC is characterized by broad inhomogeneous rim-like staining of the nuclear periphery and multiple intranuclear fluorescent foci. By contrast, "classical" p-ANCA with fine rim-like staining of the perinuclear cytoplasm are predominantly found in patients with microscopic polyangiitis (129).

The principal target antigen of p-ANCA is a matter of debate but is likely located within the cell nucleus rather than in the cytoplasm $(130,131)$. The most likely candidate antigen is betatubulin isoform 5 (TBB-5) (132). Interestingly, p-ANCA crossreact with FtsZ, which is considered an evolutionary ancestor of TBB- 5 and is widely abundant in bacteria of the human intestine (132). This highlights that abnormal immune responses to commensal bacteria might be implied in the pathogenesis of PSC.

Both cytoplasmic ANCA (c-ANCA) and p-ANCA were also found in bile fluid of patients with PSC and correlated with several adverse clinical outcomes, which might further underline their pathogenetic significance (133).

The presence of p-ANCA in serum has been associated with unfavorable clinical outcomes in patients with PSC (134). However, this notion has been challenged by other authors (135). Recently, p-ANCA have been linked to a distinct clinical phenotype of PSC with p-ANCA-positive patients being younger at disease-onset and at lower risk of cholangiocarcinoma (68). Moreover, the genotypes of p-ANCA-positive patients more often comprised the strong PSC-risk alleles HLA- $\mathrm{B}^{\star} 08$ and DRB ${ }^{\star} 03$ (68). In small-duct PSC, a more benign variant of "classical" PSC which presents with a normal cholangiogram, the prevalence, and clinical significance of p-ANCA is unclear (136).

\section{Antibodies to Biliary Epithelial Cells (BEC)}

Few studies found antibodies of different subtypes in sera of patients with PSC directed against BEC (137-140). Levels of IgA antibodies directed against BEC were correlated with adverse patient outcomes (140). Furthermore, it has been demonstrated that antibodies against BEC and bacterial lipopolysaccharides co-activate cytokine release by BEC and therefore induce biliary immune responses (139). This provides further evidence for the involvement of microbiota in the pathogenesis of PSC. Testing for anti-BEC antibodies has not been introduced into clinical practice.

\section{Antibodies Found in Patients With PSC and Additional AlH}

Additional features of AIH are found in approximately $5 \%$ of adult patients with PSC (141) but are prevalent in $35-65 \%$ of children 
with PSC $(142,143)$. In children and adolescents, the primary manifestation of disease may be that of typical AIH, together with cholangiographic and histological changes of sclerosing cholangitis (also called autoimmune sclerosing cholangitis) (142). Testing patients with PSC for ANA, anti-SMA using IFT and for antiSLA/LP using ELISA should be performed when additional AIH is suspected. Liver histology is mandatory to establish suspected $\mathrm{AIH}$ in patients with PSC, which will affect treatment decisions since AIH should be treated with immunosuppression $(1,125)$.

\section{Antibodies Against Glycoprotein 2 (Anti-GP2)}

Recently, IgA-class antibodies against glycoprotein 2 (anti-GP2 $\operatorname{IgA}$ ), which were formerly linked to severe types of Crohn's disease (144), were detected in sera of patients with PSC at a prevalence of 46.7-71.5\%. The presence of anti-GP2 IgA was strongly associated with large bile-duct involvement, development of cholangiocarcinoma, and increased mortality (3). Therefore, anti-GP2 might serve as a novel biomarker of risk stratification in patients with PSC. Moreover, evidence for the involvement of GP2 in immune responses of the intestinal mucosa to gut bacteria (145, 146) provides a further pathophysiological link to the recently discovered aberrant community structure of the gut microbiota in patients with PSC (147-149).

\section{Other Antibodies: IgG4}

IgG4-associated cholangitis (IAC) can display a cholangiographical pattern similar to PSC (150). Since patients with IAC usually benefit from treatment with corticosteroids, all patients with suspected PSC should be tested for elevated serum-IgG4 levels

\section{REFERENCES}

1. European Association for the Study of the Liver. EASL clinical practice guidelines: autoimmune hepatitis. J Heatol (2015) 63:971-1004.

2. European Association for the Study of the Liver. EASL clinical practice guidelines: the diagnosis and management of patients with primary biliary cholangitis. J Hepatol (2017) 67:145-72. doi:10.1016/j.jhep.2017. 03.022

3. Jendrek ST, Gotthardt D, Nitzsche T, Widmann L, Korf T, Michaels MA, et al. Anti-GP2 IgA autoantibodies are associated with poor survival and cholangiocarcinoma in primary sclerosing cholangitis. Gut (2017) 66:137-44. doi:10.1136/gutjnl-2016-311739

4. Manns MP, Czaja AJ, Gorham JD, Krawitt EL, Mieli-Vergani G, Vergani D, et al. Diagnosis and management of autoimmune hepatitis. Hepatology (2010) 51:2193-213. doi:10.1002/hep.23584

5. Manns MP, Lohse AW, Vergani D. Autoimmune hepatitis - update 2015. J Hepatol (2015) 62:100-11. doi:10.1016/j.jhep.2015.03.005

6. Johnson PJ, McFarlane IG. Meeting report: international autoimmune hepatitis group. Hepatology (1993) 18:998-1005. doi:10.1002/hep. 1840180435

7. Alvarez F, Berg PA, Bianchi FB, Bianchi L, Burroughs AK, Cancado EL, et al. International autoimmune hepatitis group report: review of criteria for diagnosis of autoimmune hepatitis. J Hepatol (1999) 31:929-38. doi:10.1016/ S0168-8278(99)80297-9

8. Hennes EM, Zeniya M, Czaja AJ, Parés A, Dalekos GN, Krawitt EL, et al. Simplified criteria for the diagnosis of autoimmune hepatitis. Hepatology (2008) 48:169-76. doi:10.1002/hep.22322

9. Vergani D, Alvarez F, Bianchi FB, Cançado EL, Mackay IR, Manns MP, et al. Liver autoimmune serology: a consensus statement from the committee for autoimmune serology of the international autoimmune hepatitis group. J Hepatol (2004) 41:677-83. doi:10.1016/j.jhep.2004.08.002
(124). However, $10-12 \%$ of patients with classical PSC might have increased levels of IgG4 as well (150). It is unclear to date, whether these patients represent a subgroup of PSC with a different clinical presentation or course of disease.

\section{CONCLUSION}

Testing for autoantibodies is required to diagnose $\mathrm{AIH}$ and PBC, and it may be helpful to diagnose selected patients with PSC. IFT on tissue sections and HEp-2 cells is the screening tool of choice in patients with suspected autoimmune liver disease. Immunofluorescence pattern on HEp-2 cells must be reported to correctly interpret obtained results. ELISA for anti-SLA/LP should be included in the diagnostic workup not to miss patients only presenting with these rather AIH-specific antibodies. Some of the autoantibodies may be associated with disease course, and emerging data on novel antibodies in PSC may help to elucidate the hitherto unknown pathogenesis of disease.

\section{AUTHOR CONTRIBUTIONS}

MS, CW-N, TL, and CS wrote the manuscript and reviewed the final version.

\section{ACKNOWLEDGMENTS}

MS, CW-N, and CS are supported by the DFG (SE 2665/1-1, SFB841 and KFO306). CS is supported by the Helmut and Hannelore Greve Foundation and the YAEL Foundation.

10. Tan EM, Feltkamp TE, Smolen JS, Butcher B, Dawkins R, Fritzler MJ, et al. Range of antinuclear antibodies in "healthy" individuals. Arthritis Rheum (1997) 40:1601-11. doi:10.1002/art.1780400909

11. Couto CA, Bittencourt PL, Porta G, Abrantes-Lemos CP, Carrilho FJ, Guardia $\mathrm{BD}$, et al. Antismooth muscle and antiactin antibodies are indirect markers of histological and biochemical activity of autoimmune hepatitis. Hepatology (2014) 59:592-600. doi:10.1002/hep.26666

12. Homberg JC, Abuaf N, Bernard O, Islam S, Alvarez F, Khalil SH, et al. Chronic active hepatitis associated with antiliver/kidney microsome antibody type 1: a second type of "autoimmune" hepatitis. Hepatology (1987) 7:1333-9. doi:10.1002/hep.1840070626

13. Martini E, Abuaf N, Cavalli F, Durand V, Johanet C, Homberg JC. Antibody to liver cytosol (anti-LC1) in patients with autoimmune chronic active hepatitis type 2. Hepatology (1988) 8:1662-6. doi:10.1002/hep.1840080632

14. Durazzo M, Philipp T, Van Pelt FN, Lüttig B, Borghesio E, Michel G, et al. Heterogeneity of liver-kidney microsomal autoantibodies in chronic hepatitis C and D virus infection. Gastroenterology (1995) 108:455-62. doi:10.1016/0016-5085(95)90074-8

15. Gregorio GV, Portmann B, Reid F, Donaldson PT, Doherty DG, McCartney M, et al. Autoimmune hepatitis in childhood: a 20-year experience. Hepatology (1997) 25:541-7. doi:10.1002/hep.510250308

16. Kanzler S, Weidemann C, Gerken G, Löhr HF, Galle PR, Meyer zum Büschenfelde $\mathrm{KH}$, et al. Clinical significance of autoantibodies to soluble liver antigen in autoimmune hepatitis. J Hepatol (1999) 31:635-40. doi:10.1016/ S0168-8278(99)80342-0

17. Ballot E, Homberg JC, Johanet C. Antibodies to soluble liver antigen: an additional marker in type 1 auto-immune hepatitis. J Hepatol (2000) 33:208-15. doi:10.1016/S0168-8278(00)80361-X

18. Czaja AJ, Donaldson PT, Lohse AW. Antibodies to soluble liver antigen/ liver pancreas and HLA risk factors for type 1 autoimmune hepatitis. Am J Gastroenterol (2002) 97:413-9. doi:10.1111/j.1572-0241.2002.05479.x 
19. Kirstein MM, Metzler F, Geiger E, Heinrich E, Hallensleben M, Manns MP, et al. Prediction of short- and long-term outcome in patients with autoimmune hepatitis. Hepatology (2015) 62:1524-35. doi:10.1002/hep.27983

20. Manns M, Gerken G, Kyriatsoulis A, Staritz M, Meyer zum Buschenfelde KH. Characterisation of a new subgroup of autoimmune chronic active hepatitis by autoantibodies against a soluble liver antigen. Lancet (1987) 1:292-4. doi:10.1016/S0140-6736(87)92024-1

21. Mieli-Vergani G, Vergani D, Baumann U, Czubkowski P, Debray D, Dezsofi A, et al. Diagnosis and management of paediatric autoimmune liver disease: ESPGHAN hepatology committee position statement. J Pediatr Gastroenterol Nutr (2018) 66(2):345-60. doi:10.1097/MPG.0000000000001801

22. Gregorio GV, McFarlane B, Bracken P, Vergani D, Mieli-Vergani G. Organ and non-organ specific autoantibody titres and IgG levels as markers of disease activity: a longitudinal study in childhood autoimmune liver disease. Autoimmunity (2002) 35:515-9. doi:10.1080/0891693021000056721

23. Cowling DC, Mackay IR, Taft LI. Lupoid hepatitis. Lancet (1956) 271:1323-6.

24. Liberal R, Mieli-Vergani G, Vergani D. Clinical significance of autoantibodies in autoimmune hepatitis. J Autoimmun (2013) 46:17-24. doi:10.1016/j. jaut.2013.08.001

25. Czaja AJ, Nishioka M, Morshed SA, Hachiya T. Patterns of nuclear immunofluorescence and reactivities to recombinant nuclear antigens in autoimmune hepatitis. Gastroenterology (1994) 107:200-7. doi:10.1016/ 0016-5085(94)90078-7

26. Strassburg CP, Obermayer-Straub P, Alex B, Durazzo M, Rizzetto M, Tukey RH, et al. Autoantibodies against glucuronosyltransferases differ between viral hepatitis and autoimmune hepatitis. Gastroenterology (1996) 111:1576-86. doi:10.1016/S0016-5085(96)70020-3

27. StrassburgCP,AlexB,ZindyF,Gerken G, LüttigB,MeyerzumBüschenfeldeKH, et al. Identification of cyclin $\mathrm{A}$ as a molecular target of antinuclear antibodies (ANA) in hepatic and non-hepatic autoimmune diseases. J Hepatol (1996) 25:859-66. doi:10.1016/S0168-8278(96)80290-X

28. Czaja AJ, Morshed SA, Parveen S, Nishioka M. Antibodies to single-stranded and double-stranded DNA in antinuclear antibody-positive type 1-autoimmune hepatitis. Hepatology (1997) 26:567-72. doi:10.1002/hep.510260306

29. Parveen S, Morshed SA, Arima K, Nishioka M, Czaja AJ, Chow WC, et al. Antibodies to Ro/La, Cenp-B, and snRNPs antigens in autoimmune hepatitis of North America versus Asia: patterns of immunofluorescence, ELISA reactivities, and HLA association. Dig Dis Sci (1998) 43:1322-31. doi:10.10 23/A:1018880429469

30. Beisel C, Weiler-Normann C, Teufel A, Lohse AW. Association of autoimmune hepatitis and systemic lupus erythematodes: a case series and review of the literature. World J Gastroenterol (2014) 20:12662-7. doi:10.3748/wjg. v20.i35.12662

31. Whittingham S, Irwin J, Mackay IR, Smalley M. Smooth muscle autoantibody in "autoimmune" hepatitis. Gastroenterology (1966) 51:499-505.

32. Cotler SJ, Kanji K, Keshavarzian A, Jensen DM, Jakate S. Prevalence and significance of autoantibodies in patients with non-alcoholic steatohepatitis. J Clin Gastroenterol (2004) 38:801-4. doi:10.1097/01.mcg.0000139072. 38580.a0

33. Muratori P, Muratori L, Agostinelli D, Pappas G, Veronesi L, Granito A, et al. Smooth muscle antibodies and type 1 autoimmune hepatitis. Autoimmunity (2002) 35:497-500. doi:10.1080/0891693021000054066

34. Toh BH. Smooth muscle autoantibodies and autoantigens. Clin Exp Immunol (1979) 38:621-8.

35. Wiedmann KH, Melms A, Berg PA. Anti-actin antibodies of IgM and IgG class in chronic liver diseases detected by fluorometric immunoassay. Liver (1983) 3:369-76. doi:10.1111/j.1600-0676.1983.tb00890.x

36. Frenzel C, Herkel J, Lüth S, Galle PR, Schramm C, Lohse AW. Evaluation of F-actin ELISA for the diagnosis of autoimmune hepatitis. Am J Gastroenterol (2006) 101:2731-6. doi:10.1111/j.1572-0241.2006.00830.x

37. Liaskos C, Bogdanos DP, Davies ET, Dalekos GN. Diagnostic relevance of anti-filamentous actin antibodies in autoimmune hepatitis. JClin Pathol (2007) 60:107-8. doi:10.1136/jcp.2006.039404

38. Czaja AJ, Manns MP, Homburger HA. Frequency and significance of antibodies to liver/kidney microsome type 1 in adults with chronic active hepatitis. Gastroenterology (1992) 103:1290-5. doi:10.1016/0016-5085(92)91518-9

39. Kerkar N, Ma Y, Davies ET, Cheeseman P, Mieli-Vergani G, Vergani D. Detection of liver kidney microsomal type 1 antibody using molecularly based immunoassays. J Clin Pathol (2002) 55:906-9. doi:10.1136/jcp.55.12.906
40. Gueguen M, Meunier-Rotival M, Bernard O, Alvarez F. Anti-liver kidney microsome antibody recognizes a cytochrome P450 from the IID subfamily. J Exp Med (1988) 168:801-6. doi:10.1084/jem.168.2.801

41. Manns MP, Johnson EF, Griffin KJ, Tan EM, Sullivan KF. Major antigen of liver kidney microsomal autoantibodies in idiopathic autoimmune hepatitis is cytochrome P450db1. J Clin Invest (1989) 83:1066-72. doi:10.1172/ JCI113949

42. Zanger UM, Hauri HP, Loeper J, Homberg JC, Meyer UA. Antibodies against human cytochrome P-450db1 in autoimmune hepatitis type II. Proc Natl Acad Sci U S A (1988) 85:8256-60. doi:10.1073/pnas.85.21.8256

43. Manns MP, Griffin KJ, Sullivan KF, Johnson EF. LKM-1 autoantibodies recognize a short linear sequence in P450IID6, a cytochrome P-450 monooxygenase. J Clin Invest (1991) 88:1370-8. doi:10.1172/JCI115443

44. Yamamoto AM, Cresteil D, Boniface O, Clerc FF, Alvarez F. Identification and analysis of cytochrome P450IID6 antigenic sites recognized by anti-liver-kidney microsome type-1 antibodies (LKM1). Eur JImmunol (1993) 23:1105-11. doi:10.1002/eji.1830230519

45. Bortolotti F, Vajro P, Balli F, Giacchino R, Crivellaro C, Barbera C, et al. Nonorgan specific autoantibodies in children with chronic hepatitis C. J Hepatol (1996) 25:614-20. doi:10.1016/S0168-8278(96)80228-5

46. Nishioka M, Morshed SA, Kono K, Himoto T, Parveen S, Arima K, et al. Frequency and significance of antibodies to P450IID6 protein in Japanese patients with chronic hepatitis C. J Hepatol (1997) 26:992-1000. doi:10.1016/ S0168-8278(97)80107-9

47. Duclos-Vallee JC, Hajoui O, Yamamoto AM, Jacz-Aigrain E, Alvarez F. Conformational epitopes on CYP2D6 are recognized by liver/kidney microsomal antibodies. Gastroenterology (1995) 108:470-6. doi:10.1016/ 0016-5085(95)90076-4

48. Klein R, Zanger UM, Berg T, Hopf U, Berg PA. Overlapping but distinct specificities of anti-liver-kidney microsome antibodies in autoimmune hepatitis type II and hepatitis C revealed by recombinant native CYP2D6 and novel peptide epitopes. Clin Exp Immunol (1999) 118:290-7. doi:10.1046/j.1365-2249.1999.01027.x

49. Beaune P, Dansette PM, Mansuy D, Kiffel L, Finck M, Amar C, et al. Human anti-endoplasmic reticulum autoantibodies appearing in a drug-induced hepatitis are directed against a human liver cytochrome P-450 that hydroxylates the drug. Proc Natl Acad Sci U S A (1987) 84:551-5. doi:10.1073/ pnas.84.2.551

50. Philipp T, Durazzo M, Trautwein C, Alex B, Straub P, Lamb JG, et al. Recognition of uridine diphosphate glucuronosyl transferases by LKM-3 antibodies in chronic hepatitis D. Lancet (1994) 344:578-81. doi:10.1016/ S0140-6736(94)91966-6

51. Csepregi A, Nemesanszky E, Luettig B, Obermayer-Straub P, Manns MP. LKM3 autoantibodies in hepatitis C cirrhosis: a further phenomenon of the HCV-induced autoimmunity. Am J Gastroenterol (2001) 96:910-1. doi:10.1111/j.1572-0241.2001.03383.x

52. Baeres M, Herkel J, Czaja AJ, Wies I, Kanzler S, Cancado EL, et al. Establishment of standardised SLA/LP immunoassays: specificity for autoimmune hepatitis, worldwide occurrence, and clinical characteristics. Gut (2002) 51:259-64. doi:10.1136/gut.51.2.259

53. Berg PA, Stechemesser E, Strienz J. Hypergammaglobulinämische chronisch aktive Hepatitis mit Nachweis von Leber-Pankreas-spezifischen komplementbindenden Antikörpern. Verh Dtsch Ges Inn Med (1981) 87:921-8.

54. Gelpi C, Sontheimer EJ, Rodriguez-Sanchez JL. Autoantibodies against a serine tRNA-protein complex implicated in cotranslational selenocysteine insertion. Proc Natl Acad Sci U S A (1992) 89:9739-43. doi:10.1073/ pnas.89.20.9739

55. Stechemesser E, Klein R, Berg PA. Characterization and clinical relevance of liver-pancreas antibodies in autoimmune hepatitis. Hepatology (1993) 18:1-9. doi:10.1002/hep.1840180102

56. Costa M, Rodriguez-Sanchez JL, Czaja AJ, Gelpi C. Isolation and characterization of cDNA encoding the antigenic protein of the human tRNP(Ser)Sec complex recognized by autoantibodies from patients withtype-1 autoimmune hepatitis. Clin Exp Immunol (2000) 121:364-74. doi:10.1046/j.1365-2249.2000.01280.x

57. Wies I, Brunner S, Henninger J, Herkel J, Kanzler S, Meyer zum Büschenfelde KH, et al. Identification of target antigen for SLA/LP autoantibodies in autoimmune hepatitis. Lancet (2000) 355:1510-5. doi:10.1016/ S0140-6736(00)02166-8 
58. Volkmann M, Martin L, Bäurle A, Heid H, Strassburg CP, Trautwein C, et al. Soluble liver antigen: isolation of a 35-kd recombinant protein (SLA-p35) specifically recognizing sera from patients with autoimmune hepatitis. Hepatology (2001) 33:591-6. doi:10.1053/jhep.2001.22218

59. Herkel J, Heidrich B, Nieraad N, Wies I, Rother M, Lohse AW. Fine specificity of autoantibodies to soluble liver antigen and liver/pancreas. Hepatology (2002) 35:403-8. doi:10.1053/jhep.2002.30699

60. Mix H, Weiler-Normann C, Thimme R, Ahlenstiel G, Shin EC, Herkel J, et al. Identification of CD4 T-cell epitopes in soluble liver antigen/liver pancreas autoantigen in autoimmune hepatitis. Gastroenterology (2008) 135:2107-18. doi:10.1053/j.gastro.2008.07.029

61. Zachou K, Gampeta S, Gatselis NK, Oikonomou K, Goulis J, Manoussakis MN, et al. Anti-SLA/LP alone or in combination with anti-Ro52 and fine specificity of anti-Ro52 antibodies in patients with autoimmune hepatitis. Liver Int (2015) 35:660-72. doi:10.1111/liv.12658

62. Schramm C, Herkel J, Beuers U, Kanzler S, Galle PR, Lohse AW. Pregnancy in autoimmune hepatitis: outcome and risk factors. Am J Gastroenterol (2006) 101:556-60. doi:10.1111/j.1572-0241.2006.00479.x

63. Lapierre P, Hajoui O, Homberg JC, Alvarez F. Formiminotransferase cyclodeaminase is an organ-specific autoantigen recognized by sera of patients with autoimmune hepatitis. Gastroenterology (1999) 116:643-9. doi:10.1016/ S0016-5085(99)70186-1

64. Lenzi M, Manotti P, Muratori L, Cataleta M, Ballardini G, Cassani F, et al. Liver cytosolic 1 antigen-antibody system in type 2 autoimmune hepatitis and hepatitis C virus infection. Gut (1995) 36:749-54. doi:10.1136/gut.36.5.749

65. Muratori L, Cataleta M, Muratori P, Manotti P, Lenzi M, Cassani F, et al. Detection of anti-liver cytosol antibody type 1 (anti-LC1) by immunodiffusion, counterimmunoelectrophoresis and immunoblotting: comparison of different techniques. J Immunol Methods (1995) 187:259-64. doi:10.1016/0022-1759(95)00192-X

66. Dalekos GN, Tsianos EV. Anti-neutrophil antibodies in chronic viral hepatitis. J Hepatol (1994) 20:561. doi:10.1016/S0168-8278(05)80508-2

67. Papp M, Norman GL, Altorjay I, Lakatos PL. Utility of serological markers in inflammatory bowel diseases: gadget or magic? World J Gastroenterol (2007) 13:2028-36. doi:10.3748/wjg.v13.i14.2028

68. Hov JR, Boberg KM, Taraldsrud E, Vesterhus M, Boyadzhieva M, Solberg IC, et al. Antineutrophil antibodies define clinical and genetic subgroups in primary sclerosing cholangitis. Liver Int (2017) 37:458-65. doi:10.1111/ liv. 13238

69. Marzano AV, Raimondo MG, Berti E, Meroni PL, Ingegnoli F. Cutaneous manifestations of ANCA-associated small vessels vasculitis. Clin Rev Allergy Immunol (2017) 53:428-38. doi:10.1007/s12016-017-8616-5

70. Rigopoulou EI, Roggenbuck D, Smyk DS, Liaskos C, Mytilinaiou MG, Feist E, et al. Asialoglycoprotein receptor (ASGPR) as target autoantigen in liver autoimmunity: lost and found. Autoimmun Rev (2012) 12:260-9. doi:10.1016/j.autrev.2012.04.005

71. O'Brien C, Joshi S, Feld JJ, Guindi M, Dienes HP, Heathcote EJ. Long-term follow-up of antimitochondrial antibody-positive autoimmune hepatitis. Hepatology (2008) 48:550-6. doi:10.1002/hep.22380

72. Dinani AM, Fischer SE, Mosko J, Guindi M, Hirschfield GM. Patients with autoimmune hepatitis who have antimitochondrial antibodies need longterm follow-up to detect late development of primary biliary cirrhosis. Clin Gastroenterol Hepatol (2012) 10:682-4. doi:10.1016/j.cgh.2012.02.010

73. Leung PS, Rossaro L, Davis PA, Park O, Tanaka A, Kikuchi K, et al. Antimitochondrial antibodies in acute liver failure: implications for primary biliary cirrhosis. Hepatology (2007) 46:1436-42. doi:10.1002/hep.21828

74. Muratori L, Parola M, Ripalti A, Robino G, Muratori P, Bellomo G, et al. Liver/kidney microsomal antibody type 1 targets CYP2D6 on hepatocyte plasma membrane. Gut (2000) 46:553-61. doi:10.1136/gut.46.4.553

75. Ma Y, Bogdanos DP, Hussain MJ, Underhill J, Bansal S, Longhi MS, et al. Polyclonal T-cell responses to cytochrome P450IID6 are associated with disease activity in autoimmune hepatitis type 2. Gastroenterology (2006) 130:868-82. doi:10.1053/j.gastro.2005.12.020

76. Longhi MS, Hussain MJ, Bogdanos DP, Quaglia A, Mieli-Vergani G, Ma Y, et al. Cytochrome P450IID6-specific CD8 T cell immune responses mirror disease activity in autoimmune hepatitis type 2. Hepatology (2007) 46:472-84. doi:10.1002/hep. 21658

77. Löhr H, Treichel U, Poralla T, Manns M, Meyer zum Büschenfelde KH, Fleischer B. The human hepatic asialoglycoprotein receptor is a target antigen for liver-infiltrating $\mathrm{T}$ cells in autoimmune chronic active hepatitis and primary biliary cirrhosis. Hepatology (1990) 12:1314-20. doi:10.1002/ hep. 1840120611

78. Hanot V. Etude sur une Forme de Cirrhose Hypertrophique du Foie (Cirrhose Hypertrophique ave ictere chronique). Paris: J. B. Baillere et Fils (1876).

79. Heathcote EJ. Primary biliary cirrhosis: historical perspective. Clin Liver Dis (2003) 7:735-40. doi:10.1016/S1089-3261(03)00098-9

80. Walker JG, Doniach D, Roitt IM, Sherlock S. Serological tests in diagnosis of primary biliary cirrhosis. Lancet (1965) 1:827-31. doi:10.1016/ S0140-6736(65)91372-3

81. Lu C, Hou X, Li M, Wang L, Zeng P, Jia H, et al. Detection of AMA-M2 in human saliva: potentials in diagnosis and monitoring of primary biliary cholangitis. Sci Rep (2017) 7:796. doi:10.1038/s41598-017-00906-1

82. Jopson L, Newton JL, Palmer J, Floudas A, Isaacs J, Qian J, et al. RITPBC: B-cell depleting therapy (rituximab) as a treatment for fatigue in primary biliary cirrhosis: study protocol for a randomised controlled trial. BMJ Open (2015) 5:e007985. doi:10.1136/bmjopen-2015-007985

83. Deutsche Gesellschaft für Gastroenterologie, Verdauungs- und Stoffwechselkrankheiten (DGVS) (federführend), Deutsche Gesellschaft für Innere Medizin (DGIM), Deutsche M. Crohn/Colitis ulcerosa Vereinigung (DCCV), Deutsche Leberhilfe EV; Deutsche Gesellschaft für Ultraschall in der Medizin (DEGUM), Deutsche Gesellschaft für Endoskopie und Bildgebende Verfahren (DGE-BV), et al. [Practice guideline autoimmune liver diseases - AWMF-Reg. No. 021-27]. Z Gastroenterol (2017) 55:1135226. doi:10.1055/s-0043-120199

84. Muratori L, Granito A, Muratori P, Pappas G, Bianchi FB. Antimitochondrial antibodies and other antibodies in primary biliary cirrhosis: diagnostic and prognostic value. Clin Liver Dis (2008) 12:261-276; vii. doi:10.1016/j. cld.2008.02.009

85. Braun S, Berg C, Buck S, Gregor M, Klein R. Catalytic domain of PDC-E2 contains epitopes recognized by antimitochondrial antibodies in primary biliary cirrhosis. World J Gastroenterol (2010) 16:973-81. doi:10.3748/wjg. v16.i8.973

86. Muratori P, Muratori L, Gershwin ME, Czaja AJ, Pappas G, Maccariello S, et al. 'True' antimitochondrial antibody-negative primary biliary cirrhosis, low sensitivity of the routine assays, or both? Clin Exp Immunol (2004) 135:154-8. doi:10.1111/j.1365-2249.2004.02332.x

87. Agmon-Levin N, Shapira Y, Selmi C, Barzilai O, Ram M, Szyper-Kravitz M, et al. A comprehensive evaluation of serum autoantibodies in primary biliary cirrhosis. J Autoimmun (2010) 34:55-8. doi:10.1016/j.jaut.2009.08.009

88. Berg PA, Klein R, Lindenborn-Fotinos J, Kloppel W. ATPase-associated antigen (M2): marker antigen for serological diagnosis of primary biliary cirrhosis. Lancet (1982) 2:1423-6. doi:10.1016/S0140-6736(82) 91327-7

89. Gershwin ME, Mackay IR, Sturgess A, Coppel RL. Identification and specificity of a cDNA encoding the $70 \mathrm{kd}$ mitochondrial antigen recognized in primary biliary cirrhosis. J Immunol (1987) 138:3525-31.

90. Dellavance A, Cançado EL, Abrantes-Lemos CP, Harriz M, Marvulle V, Andrade LE. Humoral autoimmune response heterogeneity in the spectrum of primary biliary cirrhosis. Hepatol Int (2012) 7:775-84. doi:10.1007/ s12072-012-9413-0

91. Metcalf JV, Mitchison HC, Palmer JM, Jones DE, Bassendine MF, James OF. Natural history of early primary biliary cirrhosis. Lancet (1996) 348:1399-402. doi:10.1016/S0140-6736(96)04410-8

92. Dahlqvist G, Gaouar F, Carrat F, Meurisse S, Chazouillères O, Poupon R, et al. Large-scale characterization study of patients with antimitochondrial antibodies but nonestablished primary biliary cholangitis. Hepatology (2017) 65(1):152-63. doi:10.1002/hep.28859

93. Moteki S, Leung PS, Coppel RL, Dickson ER, Kaplan MM, Munoz S, et al. Use of a designer triple expression hybrid clone for three different lipoyl domain for the detection of antimitochondrial autoantibodies. Hepatology (1996) 24:97-103. doi:10.1002/hep.510240117

94. Tanaka A, Nezu S, Uegaki S, Mikami M, Okuyama S, Kawamura N, et al. The clinical significance of IgA antimitochondrial antibodies in sera and saliva in primary biliary cirrhosis. Ann N Y Acad Sci (2007) 1107:259-70. doi:10.1196/ annals. 1381.028

95. Surh CD, Cooper AE, Coppel RL, Leung P, Ahmed A, Dickson R, et al. The predominance of IgG3 and IgM isotype antimitochondrial autoantibodies against recombinant fused mitochondrial polypeptide in patients 
with primary biliary cirrhosis. Hepatology (1988) 8:290-5. doi:10.1002/ hep. 1840080217

96. Rigopoulou EI, Davies ET, Bogdanos DP, Liaskos C, Mytilinaiou M, Koukoulis GK, et al. Antimitochondrial antibodies of immunoglobulin G3 subclass are associated with a more severe disease course in primary biliary cirrhosis. Liver Int (2007) 27:1226-31. doi:10.1111/j.1478-3231.2007.01586.x

97. Tana MM, Shums Z, Milo J, Norman GL, Leung PS, Gershwin ME, et al. The significance of autoantibody changes over time in primary biliary cirrhosis. Am J Clin Pathol (2015) 144:601-6. doi:10.1309/AJCPQV4A7QAEEFEV

98. Invernizzi P, Selmi C, Ranftler C, Podda M, Wesierska-Gadek J. Antinuclear antibodies in primary biliary cirrhosis. Semin Liver Dis (2005) 25:298-310. doi:10.1055/s-2005-916321

99. Nakamura M, Kondo H, Mori T, Komori A, Matsuyama M, Ito M, et al. Anti-gp210 and anti-centromere antibodies are different risk factors for the progression of primary biliary cirrhosis. Hepatology (2007) 45:118-27. doi:10.1002/hep. 21472

100. Szostecki C, Guldner HH, Netter HJ, Will H. Isolation and characterization of cDNA encoding a human nuclear antigen predominantly recognized by autoantibodies from patients with primary biliary cirrhosis. J Immunol (1990) 145:4338-47.

101. Bauer A, Habior A, Kraszewska E. Detection of anti-SP100 antibodies in primary biliary cirrhosis. Comparison of ELISA and immunofluorescence. J Immunoassay Immunochem (2013) 34:346-55. doi:10.1080/15321819.201 2.741088

102. Courvalin JC, Lassoued K, Bartnik E, Blobel G, Wozniak RW. The 210-kD nuclear envelope polypeptide recognized by human autoantibodies in primary biliary cirrhosis is the major glycoprotein of the nuclear pore. J Clin Invest (1990) 86:279-85. doi:10.1172/JCI1 14696

103. Courvalin JC, Lassoued K, Worman HJ, Blobel G. Identification and characterization of autoantibodies against the nuclear envelope lamin B receptor from patients with primary biliary cirrhosis. J Exp Med (1990) 172:961-7. doi:10.1084/jem.172.3.961

104. Wesierska-Gadek J, Penner E, Battezzati PM, Selmi C, Zuin M, Hitchman E, et al. Correlation of initial autoantibody profile and clinical outcome in primary biliary cirrhosis. Hepatology (2006) 43:1135-44. doi:10.1002/hep.21172

105. Yang F, Yang Y, Wang Q, Wang Z, Miao Q, Xiao X, et al. The risk predictive values of UK-PBC and GLOBE scoring system in Chinese patients with primary biliary cholangitis: the additional effect of anti-gp210. Aliment Pharmacol Ther (2017) 45:733-43. doi:10.1111/apt.13927

106. Sfakianaki O, Koulentaki M, Tzardi M, Tsangaridou E, Theodoropoulos PA, Castanas E, et al. Peri-nuclear antibodies correlate with survival in Greek primary biliary cirrhosis patients. World J Gastroenterol (2010) 16:4938-43. doi:10.3748/wjg.v16.i39.4938

107. Liberal R, Grant CR, Sakkas L, Bizzaro N, Bogdanos DP. Diagnostic and clinical significance of anti-centromere antibodies in primary biliary cirrhosis. Clin Res Hepatol Gastroenterol (2013) 37:572-85. doi:10.1016/j. clinre.2013.04.005

108. Honda A, Ikegami T, Matsuzaki Y. Anti-gp210 and anti-centromere antibodies for the prediction of PBC patients with an incomplete biochemical response to UDCA and bezafibrate. Hepatol Res (2015) 45:827-8. doi:10.1111/ hepr.12461

109. Mandai S, Kanda E, Arai Y, Hirasawa S, Hirai T, Aki S, et al. Anti-centromere antibody is an independent risk factor for chronic kidney disease in patients with primary biliary cirrhosis. Clin Exp Nephrol (2013) 17:405-10. doi:10.1007/s10157-012-0724-1

110. Norman GL, Yang CY, Ostendorff HP, Shums Z, Lim MJ, Wang J, et al. Antikelch-like 12 and anti-hexokinase 1: novel autoantibodies in primary biliary cirrhosis. Liver Int (2015) 35:642-51. doi:10.1111/liv.12690

111. Chazouilleres O, Wendum D, Serfaty L, Montembault S, Rosmorduc O, Poupon R. Primary biliary cirrhosis-autoimmune hepatitis overlap syndrome: clinical features and response to therapy. Hepatology (1998) 28:296-301. doi:10.1002/hep.510280203

112. Eyraud V, Chazouilleres O, Ballot E, Corpechot C, Poupon R, Johanet C. Significance of antibodies to soluble liver antigen/liver pancreas: a large French study. Liver Int (2009) 29:857-64. doi:10.1111/j.1478-3231.2009.01986.x

113. Kanzler S, Bozkurt S, Herkel J, Galle PR, Dienes HP, Lohse AW. Presence of SLA/LP autoantibodies in patients with primary biliary cirrhosis as a marker for secondary autoimmune hepatitis (overlap syndrome). Dtsch Med Wochenschr (2001) 126:450-6. doi:10.1055/s-2001-12906

114. Muratori P, Granito A, Pappas G, Pendino GM, Quarneti C, Cicola R, et al. The serological profile of the autoimmune hepatitis/primary biliary cirrhosis overlap syndrome. Am J Gastroenterol (2009) 104:1420-5. doi:10.1038/ ajg.2009.126

115. Karlsen TH, Folseraas T, Thorburn D, Vesterhus M. Primary sclerosing cholangitis - a comprehensive review. J Hepatol (2017) 67:1298-323. doi:10.1016/j.jhep.2017.07.022

116. Warren KW, Athanassiades S, Monge JI. Primary sclerosing cholangitis - a study of forty-two cases. Gut (1966) 111:23-38.

117. Hirschfield GM, Karlsen TH, Lindor KD, Adams DH. Primary sclerosing cholangitis. Lancet (2013) 382:1587-99. doi:10.1016/S0140-6736(13)60096-3

118. Takakura WR, Tabibian JH, Bowlus CL. The evolution of natural history of primary sclerosing cholangitis. Curr Opin Gastroenterol (2017) 33:71-7. doi:10.1097/MOG.0000000000000333

119. BoonstraK, WeersmaRK, vanErpecumKJ, RauwsEA,SpanierBWM, Poen AC, et al. Population-based epidemiology, malignancy risk, and outcome of primary sclerosing cholangitis. Hepatology (2013) 58:2045-55. doi:10.1002/ hep. 26565

120. Tischendorf JJW, Hecker H, Krüger M, Manns MP, Meier PN. Characterization, outcome, and prognosis in 273 patients with primary sclerosing cholangitis: a single center study. AmJ Gastroenterol (2007) 102:107-14. doi:10.1111/j.1572-0241.2006.00872.x

121. Dave M, Elmunzer MBJ, Dwamena BA, Higgins PDR. Primary sclerosing cholangitis: meta-analysis of diagnostic performance of MR cholangiopancreatography. Radiology (2010) 256:387-96. doi:10.1148/radiol.10091953

122. Burak KW, Angulo P, Lindor KD. Is there a role for liver biopsy in primary sclerosing cholangitis? Am J Gastroenterol (2003) 98:1155-8. doi:10.1111/j.1572-0241.2003.07401.x

123. Lazaridis KN, LaRusso NF. Primary sclerosing cholangitis. N Engl J Med (2016) 375:1161-70. doi:10.1056/NEJMra1506330

124. Lindor KD, Kowdley KV, Edwyn Harrison M; American College of Gastroenterology. ACG clinical guideline: primary sclerosing cholangitis. Am J Gastroenterol (2015) 110:646-59. doi:10.1038/ajg.2015.112

125. European Association for the Study of the Liver. EASL clinical practice guidelines: management of cholestatic liver diseases. J Hepatol (2009) 51:237-67.

126. Hov JR, Boberg KM, Karlsen TH, Kozarek RA, Invernizzi P. Autoantibodies in primary sclerosing cholangitis. World J Gastroenterol (2008) 14:3781-91. doi:10.3748/wjg.14.3781

127. Roozendaal C, de Jong MA, van den Berg AP, van Wijk RT, Limburg PC, Kallenberg CG. Clinical significance of anti-neutrophil cytoplasmic autoimmune liver diseases antibodies (ANCA) in autoimmune liver diseases. J Hepatol (2000) 32:734-41. doi:10.1016/S0168-8278(00)80241-X

128. Terjung B, Herzog V, Worman HJ, Gestmann I, Bauer C, Sauerbruch T, et al. Atypical antineutrophil cytoplasmic antibodies with perinuclear fluorescence in chronic inflammatory bowel diseases and hepatobiliary disorders colocalize with nuclear lamina proteins. Hepatology (1998) 28:332-40. doi:10.1002/hep.510280207

129. Terjung B, Spengler U. Atypical p-ANCA in PSC and AIH: a hint toward a "leaky gut"? Clin Rev Allergy Immunol (2009) 36:40-51. doi:10.1007/ s12016-008-8088-8

130. Terjung B, Spengler U, Sauerbruch T, Worman HJ. "Atypical p-ANCA" in IBD and hepatobiliary disorders react with a 50-kilodalton nuclear envelope protein of neutrophils and myeloid cell lines. Gastroenterology (2000) 119:310-22. doi:10.1053/gast.2000.9366

131. Terjung B, Worman HJ, Herzog V, Sauerbruch T, Spengler U. Differentiation of antineutrophil nuclear antibodies in inflammatory bowel and autoimmune liver diseases from antineutrophil cytoplasmic antibodies (p-ANCA) using immunofluorescence microscopy. Clin Exp Immunol (2001) 126:37-46. doi:10.1046/j.1365-2249.2001.01649.x

132. Terjung B, Sohne J, Lechtenberg B, Gottwein J, Muennich M, Herzog V, et al. p-ANCAs in autoimmune liver disorders recognise human beta-tubulin isotype 5 and cross-react with microbial protein FtsZ. Gut (2010) 59:808-16. doi:10.1136/gut.2008.157818

133. Lenzen H, Weismüller TJ, Negm AA, Wlecke J, Loges S, Strassburg CP, et al. Scandinavian journal of gastroenterology antineutrophil cytoplasmic antibodies in bile are associated with disease activity in primary sclerosing 
cholangitis. Scand J Gastroenterol (2013) 48:1205-12. doi:10.3109/0036552 1.2013 .825313

134. Pokorny CS, Norton ID, McCaughan GW, Selby WS. Anti-neutrophil cytoplasmic antibody: a prognostic indicator in primary sclerosing cholangitis. J Gastroenterol Hepatol (1994) 9:40-4. doi:10.1111/j.1440-1746.1994.tb01214.x

135. Lo SK, Fleming KA, Chapman RW. A 2-year follow-up study of anti-neutrophil antibody in primary sclerosing cholangitis: relationship to clinical activity, liver biochemistry and ursodeoxycholic acid treatment. J Hepatol (1994) 21:974-8. doi:10.1016/S0168-8278(05)80604-X

136. Tervaert J, van Hoek B, Koek G. Antineutrophil cytoplasmic antibodies in small-duct primary sclerosing cholangitis. Gastroenterology (2009) 136:364. doi:10.1053/j.gastro.2008.11.033

137. Xu B, Broome U, Ericzon BG, Sumitran-Holgersson S. High frequency of autoantibodies in patients with primary sclerosing cholangitis that bind biliary epithelial cells and induce expression of CD44 and production of interleukin 6. Gut (2002) 51:120-7. doi:10.1136/gut.51.1.120

138. Mandal A, Dasgupta A, Jeffers L, Squillante L, Hyder S, Reddy R, et al. Autoantibodies in sclerosing cholangitis against a shared peptide in biliary and colon epithelium. Gastroenterology (1994) 106:185-92. doi:10.1016/ S0016-5085(94)95271-X

139. Karrar A, Broomé U, Södergren T, Jaksch M, Bergquist A, Björnstedt M, et al. Biliary epithelial cell antibodies link adaptive and innate immune responses in primary sclerosing cholangitis. Gastroenterology (2007) 132:1504-14. doi:10.1053/j.gastro.2007.01.039

140. Berglin L, Björkström NK, Bergquist A. Primary sclerosing cholangitis is associated with autoreactive IgA antibodies against biliary epithelial cells. Scand J Gastroenterol (2013) 48:719-28. doi:10.3109/00365521.2013.786131

141. Kaya M, Angulo P, Lindor KD. Overlap of autoimmune hepatitis and primary sclerosing cholangitis: an evaluation of a modified scoring system. J Hepatol (2000) 33:531-42. doi:10.1034/j.1600-0641.2000.033004537.x

142. Gregorio GV, Portmann B, Karani J, Harrison P, Donaldson PT, Vergani D, et al. Autoimmune hepatitis/sclerosing cholangitis overlap syndrome in childhood: a 16-year prospective study. Hepatology (2001) 33:544-53. doi:10.1053/jhep.2001.22131

143. Feldstein AE, Perrault J, El-Youssif M, Lindor KD, Freese DK, Angulo P. Primary sclerosing cholangitis in children: a long-term follow-up study. Hepatology (2003) 38:210-7. doi:10.1053/jhep.2003.50289
144. Papp M, Sipeki N, Tornai T, Altorjay I, Norman GL, Shums Z, et al. Rediscovery of the anti-pancreatic antibodies and evaluation of their prognostic value in a prospective clinical cohort of Crohn's patients: the importance of specific target antigens [GP2 and CUZD1]. J Crohns Colitis (2015) 9:659-68. doi:10.1093/ecco-jcc/jjv087

145. Yu S, Lowe AW. The pancreatic zymogen granule membrane protein, GP2, binds Escherichia coli type 1 fimbriae. BMC Gastroenterol (2009) 9:58. doi:10.1186/1471-230X-9-58

146. Hase K, Kawano K, Nochi T, Pontes GS, Fukuda S, Ebisawa M, et al. Uptake through glycoprotein 2 of FimH + bacteria by $\mathrm{M}$ cells initiates mucosal immune response. Nature (2009) 462:226-30. doi:10.1038/nature08529

147. Kummen M, Holm K, Anmarkrud JA, Nygård S, Vesterhus M, Høivik ML, et al. The gut microbial profile in patients with primary sclerosing cholangitis is distinct from patients with ulcerative colitis without biliary disease and healthy controls. Gut (2017) 66:611-9. doi:10.1136/gutjnl-2015-310500

148. Rühlemann MC, Heinsen F-A, Zenouzi R, Lieb W, Franke A, Schramm C. Faecal microbiota profiles as diagnostic biomarkers in primary sclerosing cholangitis. Gut (2017) 66:753-4. doi:10.1136/gutjnl-2016-312180

149. Sabino J, Vieira-Silva S, Machiels K, Joossens M, Falony G, Ballet V, et al. Primary sclerosing cholangitis is characterised by intestinal dysbiosis independent from IBD. Gut (2016) 65:1681-9. doi:10.1136/gutjnl-2015-311004

150. Mendes FD, Jorgensen R, Keach J, Katzmann JA, Smyrk T, Donlinger J, et al. Elevated serum IgG4 concentration in patients with primary sclerosing cholangitis. Am J Gastroenterol (2006) 101:2070-5. doi:10.1111/j. 1572-0241.2006.00772.x

Conflict of Interest Statement: The authors declare that the research was conducted in the absence of any commercial or financial relationships that could be construed as a potential conflict of interest.

Copyright (c) 2018 Sebode, Weiler-Normann, Liwinski and Schramm. This is an open-access article distributed under the terms of the Creative Commons Attribution License (CC BY). The use, distribution or reproduction in other forums is permitted, provided the original author(s) and the copyright owner are credited and that the original publication in this journal is cited, in accordance with accepted academic practice. No use, distribution or reproduction is permitted which does not comply with these terms. 